\title{
PAJOGE ANGKONG : PESONA PEREMPUAN DALAM TUBUH LAKI-LAKI
}

\author{
Nurwahidah \\ Universitas Negeri Makassar \\ Email: idaelbahra17@gmail.com
}

\begin{abstract}
Abstrak:
Penelitian Pajoge Angkong: Pesona Perempuan dalam Tubuh Laki-Laki merupakan pelacakan untuk mengungkap kehadiran dan bentuk Pajoge Angkong dalam Masyarakat Bone dengan menggunakan pendekatan etnokoreologis dalam membedah Pajoge Angkong secara teks dan kontekstual, yang didukung dengan beberapa teori dan dituliskan secara deskriptif kualitatif. Teori bentuk digunakan untuk mengungkap elemen- elemen yang terintegrasi menjadi satu kesatuan yang utuh sebagai wujud sajian tari Pajoge Angkong serta menguak kehadiran Pajoge Angkong dalam masyarakat Bone, yang didapatkan dari wawancara, observasi, dan dokumentasi, studi Pustaka,. Hasil penelitian menunjukkan bahwa Pajoge Angkong memiliki bentuk penyajian yang tidak terlepas dari tata aturan dalam masyarakat Bone. Keseluruhan teks tari maupun teks pertunjukan Pajoge Angkong merupakan simbol yang memiliki makna dalam masyarakat Bone. Kehadiran Pajoge Angkong dalam masyarakat Bone sesungguhnya merupakan tameng bagi penari Pajoge Makkunrai pada masa lampau, masa di mana perempuan sering dijadikan objek "iseng" bagi penonton laki-laki.
\end{abstract}

Kata Kunci: Tari, Pajoge, Angkong, Bentuk, Kehadiran

\section{PENDAHULUAN}

Pajoge merupakan istilah dalam bahasa Bugis yang berasal dari kata dasar joge' yang berarti goyang/bergoyang. Penambahan awalan " $p a$ " pada kata "joge" menjadi pajoge' berarti pelaku/penari Pajoge yang sekaligus menjadi nama dari sebuah tarian yang tumbuh dan berkembang dalam masyarakat Bugis Bone. Pajoge menjadi Salah satu tarian yang terkenal dalam masyarakat Bugis Bone (Hadi, 2018).

Suku Bugis mengenal lima jenis gender, yakni Borane/Orowane (laki-laki), Makkunrai (perempuan), Calabai (laki-laki yang berpenampilan dan berprilaku seperti perempuan), Calalai (Perempuan yang berpenampilan dan berprilaku seperti laki-laki), dan Bissu (laki-laki atau perempuan yang berpenampilan dan berprilaku komplit, yakni memiliki semua sifat dan karakter dari semua jenis kelamin). (wawancara dengan Halilintar Lathief, 2005). 
Menurut Muh. Siji, Pajoge yang berkembang dalam masyarakat Bugis Bone ada dua macam, yaitu Pajoge Makkunrai dan Pajoge Angkong. Pajoge’ Makkunrai adalah Pajoge' yang ditarikan oleh gadis remaja atau perempuan (makkunrai), dan Pajoge' Angkong adalah Pajoge' yang ditarikan oleh calabai (waria/wadam). Pajoge Makkunrai tumbuh dan berkembang dalam istana, dan kemudian merambah ke luar istana yang ditarikan oleh tomaradeka/tosama (perempuan dari golongan bukan hamba tapi juga bukan dari golongan bangsawan atau golongan tenri puatateppapuata, yakni tidak diperhamba dan tidak pula memiliki hamba), dan ditarikan oleh ata (hamba sahaya) dan dipelihara oleh kaum bangsawan. (Muh. Siji, wawancara, 2006).

Pajoge' Angkong adalah Pajoge' yang ditarikan oleh calabai (waria/wadam). Kehadiran calabai dalam Pajoge di masa lampau sesungguhnya sebagai bentuk perlindungan terhadap penari Pajoge Makkunrai, karena pada masa tersebut sudah banyak penonton yang mulai iseng dengan penari Pajoge Makkunrai, terutama pada saat pementasan Pajoge Makkunrai di Pasar Malam yang diadakan di beberapa tempat seperti di Sulewatang Mpulaweng, Sulewatang Jalireng, Pompanua, Ngingo, Taccipi yang merupakan wilayah daerah Bone, bahkan terkadang sampai di luar wilayah Bone seperti ke daerah Balannipa, Bantaeng, Bulukumba dan Wajo. Dari paparan di atas, artikel ini akan mengulas bagaimana Pajoge Angkong merepresentasikan pesona perempuan dalam tubuh laki-laki dan bagaimana kontribusi Pajoge Angkong dalam melestarikan budaya tarian di Sulawesi Selatan.

\section{TINJAUAN PUSTAKA}

Dalam traktat ilmiah tari dikenal dengan nama Choreography, yang berarti karya tari. Dari kata ini kemudian dikenal istilah choreology (ilmu tentang gerak), dan choreographer (orang yang menciptakan gerak atau penata gerak). Definisi tari dikemukakan oleh beberapa ahli diantaranya: 1). Curt Sachs, "tari adalah gerak yang ritmis (Sachs, 1933), 2). John Martin, "tari adalah perwujudan tekanan emosi dalam bentuk gerak tubuh" (Nadjamuddin, 1982). 3). Pangeran Soeryadiningrat, "tari adalah gerak seluruh tubuh yang disertai dengan bunyi-bunyian (gamelan), ekspresi muka, dan gerak diserasikan dengan isi dan makna" dalam (Naziah, 2019), dan 5). Sedangkan menurut (Pramutomo, 2007) tari adalah ekspresi jiwa manusia yang 
diwujudkan dalam gerak-gerak yang ritmis dan indah.

Uraian di atas memberikan gambaran bahwa tari diungkapkan dengan menggunakan tubuh manusia sebagai media utama, sebagai ekspresi jiwa yang diproyeksi melalu keteraturan gerak baik gerak representatif maupun simbolik, dan irama yang diciptakan oleh gerak maupun sebaliknya, ataupun irama internal maupun eksternal dalam suatu ruang, baik ruang dalam tubuh maupun diluar tubuh penari yang mempunyai makna. Makna (pesan) dalam tari sebagai pembeda antara gerak keseharian dan gerak yang diproyeksi dalam sebuah tari.

Tari secara geografis dibagi menjadi dua yakni tari tradisional dan non tradisional. Tari tradisional dibagi menjadi tiga yakni tari tradisional primitif, rakyat, dan klasik. Sedangkan tari non tradisional, yaitu tari modern, post modern, kreasi, kontemporer, teater tari, dan eksperimental dance. (Lathief, 1999).

Pajoge Angkong sebagai sebuah tari akan di kaji secara tekstual (kajian tekstual) sebagai bahan pelacakan dalam bentuk penyajian tari Pajoge Makkunrai, merupakan fenomena tari dipandang sebagai bentuk secara fisik (teks) yang relatif berdiri sendiri. Tari semata-mata merupakan bentuk dan atau struktur yang tampak secara empirik dari luarnya saja (surface structure), tidak harus mengaitkan dengan struktur dalamnya (deep structure)" (Hadi, 2007). Hal tersebut sejalan dengan pendapat Anya Peterson Royce dalam Anthropology of The Dance, bahwa bentuk tari, yakni membahas tentang struktur yang mengkaji tari dari pendekatan tekstual" (Royce, 1980). Dengan demikian Pajoge Angkong sebagai sebuah bentuk tari akan dikaji berdasarkan konsep koreografis (analisis koreografis) yang meliputi unsur penari, gerak, pola lantai, musik tari, tempat pertunjukan, kostum, tata rias, dan properti, sebagai keutuhan dalam sebuah komposisi tari atau koreografi. Sebagai penegas Marco de Marinis mengemukakan, bahwa teks seni pertunjukan berbeda dengan teks linguistik yang single layers yaitu bahasa. Teks pertunjukan tidak hanya multikode atau multidimensi, akan tetapi juga direkayasa dari bermacam-macam media ekspresi, yang menunjukkan bahwa teks seni pertunjukan sebagian besar secara material selalu berbeda dan kompleks karena multi layers, yaitu semua elemen dari seni pertunjukan di antaranya penari, gerak, musik tari, tempat pertunjukan, busana tari, properti dan lain-lain (De Marinis, 1993). Selain kajian tekstual juga mengkaji secara kontekstual dengan menempatkan seni (Pajoge Angkong) sebagaimana pandangan masyarakat pemilik kesenian tersebut (emik), yakni 
menempatkan fenomena kesenian dalam konteks yang lebih luas, yakni konteks sosial budaya yang di teliti/deep structure(Ahimsa-Putra, 2000).

\section{METODE PENELITIAN}

Tulisan ini mengulas Pajoge Angkong dengan sumber data utama dalam artikel ini adalah hasil wawancara mendalam dengan nara sumber yang merupakan pelaku/penari Pajoge, yakni Mak Noneng, salah seorang Penari Pajoge Makkunrai pada tahun 40-an, bersama mami Fitri (Fitri Pabentengi/Abdul Muin) salah seorang Bissu, Ketua Perkumpulan Waria Sulawesi Selatan, Pemerhati Budaya Bugis Bone, dan pendiri Sanggar Seni Arung Palakka (Arpal) dengan sekretariat di Bola Soba (Rumah Besar/Rumah Raja), sekaligus tempat tinggal mami Fitri dan Bissu lainnya sebagai pengelola/penjaga Bola Soba, serta mami Angel (Puang Matoa Bissu Bone pengganti mami Fitri Almarhum), Puang Bulan (Maestro Pajoge Angkong Bone), dan Puang Macora (Maestro Pajoge Angkong Bone). Selain itu, kajian Pustaka sebagai sumber data sekunder juga digunakan sebagai bagian dari Teknik pengumpulan data.

Penelitian yang berlokasi di wilayah daerah Bone dan beberapa daerah yang merupakan tempat berkembangnya Pajoge Angkong ini, menggunakan pendekatan etnokoreologis (teks dan kontekstual) dengan penekanan data secara emik dan tentunya di sajikan dalam bentuk etik.

\section{HASIL DAN DISKUSI}

\section{Struktur Personil dalam Pajoge Angkong}

Keberadaan Pajoge Angkong di Kabupaten Bone mulai pada abad ke-19, pada masa pemerintahan La Mappanyukki Datu Lolo ri Suppa, Raja Bone ke-32. Awal mula adanya Pajoge Angkong diinspirasi oleh Sere Bissu yang mereka saksikan dalam pertunjukan yang kemudian tarian mereka disebut sebagai Mallebbang Sere yang berarti memperluas atau mengembangkan Gerakan (Johariana, 2018).

Dalam buku (Holt, 1939) Dance Quest in Celebes, Holt menyebut Pajoge Angkong sebagai Wandu-Padjoge/Pajoge Wandu, yang dalam satu gerakannya disebut gerak bergandengan tangan (dancing wandu in a figure with joined hands). Buku tersebut berisi tentang laporan perjalanan tim penelitian tari yang disponsori 
oleh Les Archives Internasionales de La Danse Paris, yang beranggotakan Rolf de Mare', Hans Evert, dan Claire Holt. Perjalanan singkat selama sepuluh hari namun produktif tersebut, menelusuri jejak tari tradisional di Sulawesi Selatan mulai dari kota Makasar, dilanjutkan ke arah utara yakni ke Pangkajene, Tanah Toraja, Luwu, Sengkang, Pompanua, dan balik lagi ke kota Makassar. Sekalipun judul buku tersebut Dance Quest in Celebes (Penelitian/Pencarian Tari di Sulawesi), akan tetapi perjalanan dan penelitian tari yang dilakukan tidak menjangkau seluruh wilayah Sulawesi (Celebes), melainkan daerah Sulawesi Selatan bagian utara saja yang dimulai dari Makasar, Pangkep, Tator, Luwu, Wajo, dan Bone. Dengan demikian daerah Mandar yang sekarang sudah terpisah dengan Sulawesi Selatan menjadi Sulawesi Barat, serta daerah pesisir selatan yang mayoritas berpenduduk etnis Makasar tidak terjangkau dalam penelitian. Namun demikian materi dalam buku tersebut sangat penting dan sangat membantu bagi pengetahuan tari tradisional Sulawesi Selatan yang sebagian besar hampir tidak berjejak lagi, terutama dalam pendokumentasian beberapa gerak Pajoge Angkong yang disebut Holt Padjoge Wandu.

Puang Macora mengemukakan, bahwa dalam setiap kelompok Pajoge Angkong terdiri dari 1). Emma Genrang, yakni seorang waria yang bertugas memimpin dan mengkoordinir semua kegiatan Mappajoge yang diadakan oleh bangsawan, baik di pasar malam maupun di tempat-tempat lainnya, seperti di bawah pohon besar yang biasa di adakan di kampung-kampung baik di Bone maupun di luar wilayah Bone, serta mengkoordinir semua penari, dan pemusik, serta orang-orang yang terlibat dalam kelompok Pajoge. Emma Genrang sekaligus bertugas sebagai pemusik dalam Pajoge Angkong, 2). Indo Genrang adalah seorang waria yang bertugas sebagai paggenrang (pemain gendang), dan terkadang menjadi passitta elong (penyanyi) dalam mengiringi Pajoge Angkong, 3). Pangibing adalah laki-Iaki yang berperan sebagai pendamping atau pengawal Pajoge pada saat salah satu dari penonton mappasompe (memberi hadiah kepada Pajoge). Hal ini terjadi manakala salah seorang dari penonton, yang biasanya dari kaum bangsawan, atau orang kaya terjadi konta (menyukai/tertarik) dengan salah seorang Pajoge. Kehadiran Pangibing tidak menjadi sebuah keharusan dalam kelompok Pajoge Angkong, karena pada dasarnya penari Pajoge Angkong dapat menjaga diri dari laki-laki yang iseng, dan sesungguhnya merekapun dapat memunculkan watak laki-laki tulennya ketika merasa terganggu. Bahkan penari Pajoge Angkong, biasanya semakin di soraki oleh 
penonton semakin bersemangat menari, semakin kapuji-pujiang (semakin bertingkah/bergerak untuk menarik perhatian), bahkan kalaupun digeniti/diisengi sama penonton biasanya mereka semakin suka, apalagi yang menggeniti/mengisengi adalah laki-laki yang diincar selama ini (disukai), 4). Pappocci, adalah seorang waria yang masih berstatus magang/belajar atau penari Pajoge Angkong pemula, belum memiliki pengalaman manggung yang baik. Biasanya mereka diberikan peran sebagai solois (penyanyi) di awal-awal pertunjukan sebagai ajang memperkenalkan kepada penonton, atau sebagai penari cadangan, manakala salah satu dari anggota Pajoge Angkong senior berhalangan, 5). Pallampu Strongkeng/Lampu Gase, adalah seseorang yang bertanggung jawab sebagai teknisi lampu: menyiapkan, menyalakan, mematikan dan memperbaiki lampu manakala terjadi kerusakan. Sebelum kelompok Pajoge menggunakan lampu strongkeng mereka menggunakan cahaya obor, bahkan sinar rembulan di malam hari sebagai penerang alami. Pallampu Strongkeng/Lampu Gase boleh waria atau laki-laki tulen yang penting disepakati/disetujui oleh pimpinan Pajoge Angkong (Emma' Genrang). (wawancara Puang Macora, salah seorang penari Pajoge Angkong di Bone, 2008).

Mami Fitri sudah terlebih dahulu menjelajahi Pajoge Makkunrai dan Pajoge Angkong, mengajarkan di sanggar, dan mementaskan Pajoge Makkunrai dan Pajoge Angkong di berbagai event, jauh sebelum penulis menelusuri Pajoge secara aktif yang di mulai pada tahun 1995. Sebagai penguat dari validnya data, setiap kali berkunjung ke Bone, pastilah menemui mami Fitri terlebih dahulu dan bersama-sama ke rumah Mak Noneng. Terutama pada saat akan menggali gerak Pajoge, serta ditemani dan didampingi oleh Muhammad Imran, salah seorang guru Seni dan pemusik Pajoge yang biasa mengiringi Mak Noneng dalam setiap pementasannya di tahun 90-an. Sumber primer lainnya adalah Muhammad Siji, salah seorang pensiunan guru dan Kasi. Seni di Bone dan merupakan salah seorang penari Pajaga Andi Burane pada saat Andi Mappanyukki Sultan Ibrahim menjadi Raja di Bone, dan penulis "Sekelumit Tentang Tari Pajoge” yang masih dalam bentuk stensilan.

Penari Pajoge Angkong seperti halnya dengan penari Pajaga Makkunrai harus berjumlah genap, karena ditarikan secara berpasangan yakni 2, 4, 8, 10, 12, dan seterusnya dalam jumlah genap, sesuai dengan kebutuhan pementasan. Pada zaman dahulu penari Pajoge dipilih dan ditetapkan oleh pemilik kelompok Pajoge, yang 
biasanya di koordinir oleh raja, atau turunan bangsawan atas koordinasi dengan Emma' Genrang.

Setiap penari Pajoge Angkong memiliki nama panggung yang kemudian melekat dalam keseharian. Biasanya nama lahir/asli mereka sudah tidak diketahui oleh masyarakat, bahkan dalam kelompok mereka sendiri. Misalnya Puang Macora, salah seorang penari Pajoge Angkong, diberi gelar/nama panggung Macora, karena ketika ia naik panggung wajahnya tampak sangat cantik dan bercahaya (macora) bagaikan mentari yang baru terbit dan mengalahkan kecantikan seorang perempuan. Nama lain adalah Puang Bulang, di gelar Puang Bulang karna wajahnya begitu indah, laksana bulan purnama yang memancarkan pesona ketika berada di atas panggung. Sebahagian yang lain dijuluki dengan nama panggung yang di ikuti dengan nama asal kampung mereka, seperti Bintang Labembe (Bintang yang berasal dari kampung Labembe), Cinta Watu (cinta dari kampung Watu), Cahaya Wedda (Cahaya dari kampung Wedda), Macora Bone (Macora dari Bone), Bulang Barebbo (Bulang dari Barebbo) dan lain-lain. (wawancara dengan Puang Macora, Bone 2009).

\section{Pajoge Angkong : Pesona Perempuan dalam Tubuh Laki-Laki}

Kehadiran Pajoge Angkong sebagai tontonan hiburan dalam masyarakat tidaklah semulus, dan seindah wajah dan nama mereka. Sebahagian masyarakat mengelu-elukan kehadiran mereka terutama kaum pria, dan sebahagian lainnya menganggap mereka sebagai pengganggu rumah tangga yang harus dimusnahkan dari muka bumi. Tersebutlah beberapa rumah tangga harus berantakan karena ulah dari sang suami yang rela meninggalkan istri dan anak demi seorang penari Pajoge Angkong. Mereka rela mengeluarkan duit banyak untuk mendapatkan Pajoge yang diinginkan, terutama yang menjadi primadona dalam satu kelompok. Hal ini disebabkan karena dalam pementasan Pajoge, penonton dipersilahkan untuk melakukan interaksi langsung dengan penari, manakala sudah terjadi konta'/takkonta (jatuh hati dengan salah seorang Pajoge). Mereka yang sudah konta' akan mendatangi Pajoge tersebut dan dengan didampingi oleh Pangibing, sang penonton (laki-laki/pappasompe/pemberi saweran) akan meminta kepada Pajoge utuk melakukan gerak Ballung (kayang), dan terkadang sanggul penari menyentuh badan sang Pappasompe. Biasanya hadiah diberikan sebelum dan setelah melakukan gerak Ballung. Hadiah tersebut terkadang berupa uang, emas, sapu tangan, minyak 
wangi atau benda-benda berharga lainnya. Jika hadiah tersebut berbentuk uang maka akan dikumpul kepada Emmak Genrang/Indo Pajoge untuk di bagi sesuai peran masing-masing. Jika berbentuk barang maka benda tersebut menjadi hak milik Pajoge yang diberikan hadiah.

Pertunjukan Pajoge Angkong sangat banyak orderannya, dan tidak perlu menunggu kegiatan Pasar Malam yang dilaksanakan di suatu kampung. Salah satu tempat yang menjadi lokasi favorit Pajoge Angkong adalah desa Kampiri. Desa ini merupakan wilayah Wajo dan berbatasan dengan wilayah Bone. Menurut cerita beberapa masyarakat Kampiri yang berumur 60-an atau 70-an tahun ke atas, bahwa pertunjukan Pajoge Angkong sering diadakan di Kampiri di sekitar tahun 40-an, mereka melakukan Pajoge Angkong/Mappajoge di bawah pohon besar, dan biasanya dibawah Fong Cempa Loppo (Pohon Asam yang besar)..

"Lokasinya di sana, dekat rumah nenek Dawi-mu, tepatnya di belakang rumah H. Mintang sekarang", kata Fuang Tija. Hampir tiap hari/ malam mereka mereka melakukan pertunjukan. Jika jam sudah menunjukkan sekitar jam dua siang, moninitu genrangnge, maddepungenni tau-e, tapi orowane manengmi, yaccang makkunraiyye lokka manontong. Ia manontongka nasaba anak-anakka, deewisse bettuanna, jokkatoma bawang maccule, kuseddena to-maega-E, dessa wattungka melo manontong. Mompomanennitu calabeyye, engkana mabbaju tokko, engaktona mabbaju de naijei pada pakambangnge, nappa isio tengngana, engkatona mabbaju pada kobaja-e, nappa pake sigera. Nakko mettanita massere-massere, engkanatu matu calabei irenreng messu lokka dare-e, mabela limonri, deewisseng aga napegau. Maggau salani kapang. Nasaba biasa engkana baine emosi, nasaba deena nalisulisu lakkenna, mengkalingatoni carita makkeda engkatu lakkemmu renreng calabai ku dare-E. Biasa aga masserang. (sekitar jam 2 siang, gendang sudah mulai di bunyikan, masyarakat mulai berdatangan dan berkumpul, tapi hanya laki-laki, perempuan di larang datang menonton. Saya sebagai perempuan berada di sana, karena saya hanya datang main di dekat keramaian, bukan sengaja mau menonton. Jika mereka sudah lama menari dan di beri hadiah. Maka seorang waria akan di tarik oleh seorang laki-laki ke kebun di belakang pohon besar, 
saya tidak tau mereka melakukan apa. Mungkin mereka melakukan hal yang tidak-tidak. Terkadang ada seorang perempuan yang emosi dan memarahi suaminya, mungkin karena mereka sudah mendengar kabar bahwa suaminya bersama dengan seorang waria di kebun (semaksemak) dan melakukan hal-hal yang tidak senonoh. Terkadang mereka berakhir dengan perceraian. (wawancara dengan Fuang Tija, Kampiri 2010).

Pajoge Angkong yang menjadi primadona dalam kelompok ini bernama Indo Wero (nama calabai-nya), perawakannya matanre (tinggi), macole (lansing), dan mapute fincengmani olina (kulitnya putih bersih bak piring keramik cina). Dalam setiap pertunjukan Indo Wero paling banyak mendapat pappasompe (saweran/hadiah) dari para penonton, dan paling sering diajak kencan oleh penonton laki-laki yang memberi hadiah. Kelompok Pajoge Angkong ini bukan berasal dari desa Kampiri, tapi tauttama-tama (orang yang masuk ke Kampiri/pendatang tapi tidak menetap) dan kemungkinan terbesarnya adalah Pajoge Angkong dari Bone karena Kampiri merupakan desa perbatasan antara Bone dan Wajo. Banyak calabai di Kampiri pada waktu itu, tapi mereka tidak pernah majjoge tapi makkindobottingmi na mattennung (hanya menjadi inang pengantin/perias pengantin dan menenun sarung sutera). (wawancara Fuang Tija, Kampiri 2008).

Pertunjukan Pajoge Angkong tersebut di atas terkadang berakhir sampai pagi. Laki-laki yang datang menonton kebanyakan mabboto (main judi), massaung manu-i nappa nataroi taji (engkatu pada jarung karungnge) ku ajena manu-e (menyabung ayam dengan menggunakan taji pada kaki ayam). Mereka yang datang bukan hanya dari rakyat biasa, tapi ada juga tentara kota, sebutan dari tentara yang bertugas mengamankan wilayah Sulawesi Selatan dari pemberontakan DI-TII pasca kemerdekaan. Penyebutan tersebut untuk membedakan dengan tentara ale'/gorilla (tentara hutan/gerilya) yang merupakan pasukan/tentara pemberontak yang dipimpin oleh Kahar Muzakkar.

Kebanyakan tentara tersebut di datangkan dari daerah Jawa untuk mengamankan wilayah Sulawesi Selatan dari pemberontakan Gorilla/tentara ale' (gerilya/tentara hutan/ pasukan DI/TII Kahar Muzakkar). Jika ada 
pemeriksaan/penggeledahan, maka pertunjukan tidak dilaksanakan lagi.

Pemeriksa yang dimaksudkan adalah sekelompok tentara kota yang datang untuk mengamankan kampung dari keramaian, karena menimbulkan dan memarakkan perjudian, dan terkadang menimbulkan perselisihan dan keresahan dalam masyarakat. Tapi kelompok Pajoge Angkong tidak pernah tertangkap. Karena yang datang memeriksa dan akan di periksa sebahagian adalah diantara mereka tentara kota yang sering terlibat dalam pementasan Pajoge Angkong dan memback-up mereka, yang terlebih dahulu membocorkan informasi jika akan diadakan penggeledahan.

Salah satu hal yang melekat pada Pajoge Angkong adalah, kharisma dan pesona yang dimiliki melebihi kaum perempuan. Hal tersebut tidak lepas dari upaya gigih yang dilakukan Pajoge Angkong dalam merawat diri baik dari dalam maupun dari luar. Baik menggunakan ramu-ramuan maupun kekuatan magis yang membuat kecantikan mereka memancar di atas panggung. Tidak tanggung-tanggung seorang Pajoge akan mencari ilmu kebatinan sampai dipelosok-pelosok kampung, terutama ilmu tentang bagaimana cara memikat mata-hati dari pada kaum laki-laki dan pappasompe yang datang menonton. Salah satu ilmu pemikat yang digunakan adalah cenningrara. Cenningrara berupa bacaan yang berbahasa Bugis kemudian ditiupkan ke bedak, pada saat menggunakan alis, lipstik, memakai kostum dan lain-lain yang tujuannya untuk memikat hati orang lain atau lawan jenis. Ilmu lainnya adalah ilmu Pappanguju (mempersiapkan diri untuk melakukan aktifitas) atau ilmu lettuppoMujokka (sampai dulu baru keluar rumah), bacaan untuk keselamatan dalam beraktifitas. Serta ilmu untuk menghipnotis (Paremma') penonton untuk berbetahbetah duduk menonton sampai larut malam bahkan sampai pagi, dan tidak segansegan mengeluarkan uang banyak dan benda-benda berharga untuk mappasompe (memberi saweran/hadiah) kepada Pajoge, dan ilmu Paggera' (ilmu untuk menundukkan lawan dengan bentakan/suara keras). Ilmu-ilmu tersebut wajib di miliki oleh Emma' Genrang/Indo Pajoge, karena hal tersebut merupakan salah satu syarat yang menjadikan ia terpilih sebagai Emma' Genrang. Kesaktian yang dimiliki harus melebihi dari anggota lainnya.

Dalam pertunjukan Pajoge Angkong terdapat beberapa ragam gerak yang biasa di tampilkan. Ragam gerak di bawah terkadang di tarikan semuanya oleh penari Pajoge Angkong dan adakalnya hanya sebahagian, tergantung suasana pertunjukan, 
serta penomoran ragam tersebut dibawah ini bukan sebuah urutan, kecuali ragam pertama (Lamba Sari) dan ragam Massimang (Mohon pamit). Dalam situasi wawancara dengan nara sumber, yakni dengan Puang Macora dan Puang Bulang, gerak-gerak yang ditampilkan tidak berurutan, jika diminta untuk melakukan ulang. pasti ada perbedaan. Demikian halnya ketika menyaksikan pertunjukan mereka berdua di atas panggung, terkadang mereka ngobrol dengan jelas untuk memberi kode gerak selanjutnya, karena terkadang gerak yang akan atau dilakukan Puang Macora berbeda dengan gerak yang akan atau dilakukan oleh Puang Bulang. Tapi obrolan mereka di atas panggung tidaklah mengurangi keindahan gerak, melainkan semakin menampakkan ciri tari rakyat yang spontan dan menghibur. Secara teknis hal inipun wajar terjadi jika gerak tersebut terkadang berbeda susunanya dalam panggung yang berbeda, karena kedua penari Pajoge Angkong tersebut sudah berusia senja/lanjut dan tinggal mereka berdua yang diketahui keberadaannya sampai sekarang. Ragam gerak yang akan diuraikan dibawah ini, selain hasil wawancara dengan Puang Bulang, Puang Macora, mami Fitri, mami Angel juga beberapa hasil wawancara secara tidak langsung (perbincangan) dengan beberapa praktisi dan peneliti tari Pajoge Angkong diantaranya Halilintar Lathief, dan Andi Jamilah. Ragam gerak tersebut adalah: 1). Lamba Sari/ Lambang Sari (gerak berjalan memasuki arena), 2). Ragam Sere Jengki/se-ibing (berdempetan), 3). Ragam gerak Dung dung ce' (gerak sesuai dengan irama gendang), 4). Ragam gerak Magganda-ganda (gerak sesuai dengan irama lagu), 5). Ragam gerak siballungi (melakukan gerak kayang secara bergantian)6). Ragam Gerak Ballung (Kayang), 7). Sere Biasa (Gerak Biasa)/Sere Pamasari, 8). Sere Massimang (Mohon Pamit). Penomoran ragam tersebut bukan sebuah urutan, kecuali ragam pertama (Lamba Sari) dan ragam Massimang (Mohon pamit). Hal ini dikarenakan oleh nara sumber (puang Macora/Daeng Macora dan Puang Bulang/Daeng Bulang), pada beberapa pementasan selalu berbeda urutan gerak yang dilakukan di atas panggung. Olehnya itu untuk menghindari kesalahan data dan untuk kerapian tulisan, maka gerak tetap diberikan penomoran akan tetapi bukan nama urutan gerak dalam Pajoge Angkong.

Musik tari Pajoge Angkong yaitu dua buah genrang (gendang) dan kadangkadang di tambah satu buah gong, jika alat tersebut (gong) tersedia dalam kelompok Pajoge. Alat musik yang wajib ada adalah dua buah genrang (gendang), serta 
lantunan syair yag dinyanyikan oleh indo pajoge /emma'genrang.

Irama (pukulan) yang dihasilkan oleh perpaduan gendang yang dipukul (ditette) dengan alat musik lainnya, yakni terdiri dari tette Pangolli ( pukulan/musik pemanggil untuk berkumpul), tette palari (pukulan/irama cepat), tette malalengmpenni (pukulan/musik tengah malam), dengan syair yang berisi tentang petuah/nasehat (elong malamung bettuanna/ lagu yang dalam maknanya) tentang kehidupan dan syair yang penuh makna cinta yang mendalam, seperti syair lagu Ininnawa Sabbarakki (Hati yang penuh kesabaran), Masa Alla (Maa syaa ALLah), Indo Logo (gelaran buat perempuan/gadis), Bulu Alau'na Tempe (Gunung di sebelah timur tempe). (wawancara dengan Halilintar Lathief, 2005).

Berbeda dengan Pajoge Makkunrai, Pajoge Angkong sejak muncul dan berkembangnya tidak pernah dipentaskan di istana seperti Pajoge Makkunrai. Pajoge Angkong dipentaskan di acara Pasar Malam dan di tempat-tempat berkumpulnya masyarakat, misalnya di bawah pohon besar. Mak Noneng mengemukakan, bahwa Pasar Malam biasanya di adakan di Sulewatang Mpulaweng, Sulewatang Jalireng, Pompanua, Ngingo, Taccipi yang merupakan wilayah daerah Bone, bahkan terkadang sampai ke daerah Balannipa, Bantaeng, Bulukumba dan Wajo. Untuk masuk dalam area pasar malam, masyarakat harus membeli tiket tanda masuk yang di jaga oleh Opas/ polisinna Datu-E/Pangongranna Datu-E (polisi/security/penjaganya) raja/kerajaan. Dalam Pasar malam selain pementasan Pajoge juga menyediakan sarana permainan rakyat, seperti mattado (permainan yang menggunakan tali pengait, dan beberapa binatang ternak unggas, yang pada umumnya adalah bebek), dadu, unta-unta, king-lotto, kece-maggulaceng, maddempe nomoro, golo-golo,dan lainlain. Akan tetapi menurut Mak Nonneng sekalipun banyak sarana permainan yang disiapkan akan tetapi manakala gendang Pajoge di mulai maka semua penonton akan berbondongbondong ke arena pentas dan meninggalkan sarana permainan lainya. (wawancara dengan Mak Nonneng, penari Pajoge di era 40-an, di Watangpone, 2006).

Tata rias yang di gunakan penari Pajoe Angkong pada era tahun 40-an sama dengan tata rias yang digunakan oleh Pajoge Makkunrai, yakni tata rias cantik dengan menggunakan bedda batu (bedak yang mempunyai dua warna, yakni putih; dan warna kulit) , dan rencong papeng (lipstik segi empat) yang terbuat dari serbuk merah. Cara menggunakan rencong papeng, mulut harus dibasahi terlebih dahulu, kemudian di olesi dengan serbuk merah dengan menggunakan tangan. 
Tata rias lainnya, adalah dadasa,yakni alat rias yang terbuat dari pelleng (kemiri) yang di bakar dan taibani/tai awani (lilin yang terbuat dari kotoran lebah) yang dibakar sehingga menghasilkan warna hitam yang mengkilat dan berminyak. Perpaduan kedua benda tersebut yakni pelleng/felleng dan tai bani/tai awani yang di bakar dan menghasilkan warna hitam mengkilat dan berminyak di sebut minynyak patti (minyak yang bergetah/mappatti). Minynyak Patti tersebut di riaskan pada bahagian dahi penari, menyerupai kelopak bunga yang disebut dengan dadasa.

Perkembangan selanjutnya masyarakat Bugis Bone tidak lagi menyebut minynyak patti ketika akan membuat riasan dadasa (bentuk riasan yang bermotif kelopak bunga pada dahi dan berwarna hitam), tapi digantikan dengan dadasa yang mempunyai dua makna, yakni sebagai salah satu bentuk tata rias pada wajah/dahi dan sebagai alat rias.

Dewasa ini tata rias penari sudah menggunakan alat make-up yang tersedia di pasaran, dan di sesuaikan dengan selera pemakainya. Sehingga garis-garis kecantikan penari semakin tampak, karena selain alat rias yang semakin lengkap juga kemahiran penata rias semakin up to date, dengan munculnya dan berjamurnya MUA (Make Up Artist) dibeberapa daerah yang memiliki teknik rias yang bervariasi dan menjadikan wajah penari sangat berbeda dengan wajah aslinya ketika belum make-up (Make Over)

Tata Busana yang di gunakan penari Pajoge Angkong sama halnya yang digunakan oleh Pajoge Makkunrai, yakni baju pakambang (baju yang tidak di jahit, dan menyerupai selendang), Iipa sabbe (sarung sutera), dan passio pakambang (pengikat baju). Perkembangan selanjutnya penari menggunakan baju tokko labbu, atau dalam satu pementasan menggunakan kombinasi baju tokko dan baju pakambang yang bertujuan untuk mempermudah secara teknis, juga menambah kesan estetis dalam pementasan tari Pajoge.

Perhiasan tari Pajoge Angkong adalah, sebuah jungge yang di pasang di atas kepala,geno sirue (kalung panjang), dan potto tiggero tedong (gelang panjang), dan ating-anting atau bangkara. Kostum dan aksesori yang tersebut di atas masih digunakan Pajoge Angkong yang tergabung dalam sanggar Arung Palakka pimpinan mami Fitri (Almarhum), yang rata-rata masih berusia belia/muda. Pe nari Pajoge Angkong yang sudah sepuh, seperti Puang Macora dan Puang Bulang menggunakan kostum kebaya modern dan sarung yang sudah dijahit berbentuk rok, atau sarung 
sutera yang dipasang dengan menggunakan stagen seperti menggunakan kain sarung tanpa jahitan. Hiasan kepala Pajoge Angkong hanya menggunakan sanggul serta hiasan kepala/kembang sanggul yang sederhana, serta perhiasan kalung, anting/bangkara dan gelang yang simpel, seperti yang digunakan perempuan pada umumnya pada saat akan ke pesta. Hal ini dilakukan untuk keluwesan gerak penari Pajoge Angkong yang sudah sepuh/ usia lanjut, dan mereka tidak terbebani dengan aksesori yang bisa mengurangi gerak dan kefokusan penari di atas panggung. Adapun property yang digunakan adalah sebuah papi/kipasa (kipas). Secara teknis kipas menjadi penguat dalam pertunjukan, juga menambah kesan estetis pertunjukan tari Pajoge.

Pementasan Pajoge Angkong tidak dibatasi durasi waktu, tarian mereka berlangsung selama ada penonton yang menyaksikan dan memberi saweran. Semakin banyak penonton yang menyawer, semakin lama pula Penari Angkong mementaskan tariannya. Menurut Wilani, ragam gerak tarian Pajoge Angkong bertujuan sebagai hiburan untuk masyarakat penggemarnya dan sebagai sumber mata pencaharian bagi pelakunya/Pajoge Angkong (Risni Wilani, Makna Ragam Gerak Tari Pajoge Angkong di Kecamatan Ranete Riattang Kabupaten Bone, 2013).

\section{Kontribusi Pajoge Angkong dalam Melestarikan Budaya Tari di Sulawesi Selatan}

Mereka yang terpilih sebagai Pajoge otomatis memiliki akses terbaik dengan keluarga bangsawan dan dilindungi oleh bangsawan. Terpilihnya merekapun adalah sebuah kebanggan dan kehormatan. Jika terdapat salah seorang Pajoge yang melakukan hal-hal yang kurang berkenan, maka hal tesebut adalah oknum, tidak mewakili semua Pajoge, dan hal tersebut kembali kepada pribadi masing-masing, dan boleh saja hal tersebut terjadi pada siapapun dan profesi apapun. Tersebutlah Mak Noneng sebagai generasi terakhir dari Pajoge Makkunrai era 40-an, serta Puang Macora dan Puang Bulan (Maestro Pajoge Angkong) sangatlah jauh dari kesan seperti dalam stigma masyarakat Bugis Bone masa lampau. Puang Macora, Puang Bulan sebagai Pajoge Angkong dan Mak Noneng telah membuktikan bahwa sebagai Pajoge Makkunrai, Mak Noneng dan anak keturunannya diterima dan diapresiasi di semua kalangan dengan baik, dan ia sangat bangga menjadi seorang Pajoge Makkunrai. 
Di era sekarang Pajoge, baik Pajoge Angkong maupun Pajoge Makkunrai sebagai sebuah tarian tidaklah menjadi momok bagi masyarakat Bugis Bone. Bahkan orang tua mengizinkan anak-anak mereka untuk belajar tari Pajoge pada sanggarsanggar tari yang terdapat di Bone. Selain karena Pajoge telah bermetamorfoses dari panggung yang sesungguhnya, juga karena makna yang terdapat dalam gerak dan syair yang mengiringi lebih kepada kesan estetis yang mengagungkan keindahan perempuan yang harus ditempatkan pada posisi yang mulia dalam hidup dan penghidupan. Hal lain adalah animo dan apresiasi masyarakat terhadap seni, khususnya seni tari semakin baik. Masyarakat Bugis Bone lebih senang anak gadis dan anak laki-laki mereka berkumpul dan menghabiskan waktu di sanggar untuk belajar tari daripada lao solle (pergi ke sana-kemari) dengan tujuan tidak jelas. Apalagi event-event lomba tari dan festival banyak dilaksanakan dalam wilayak Lokal. Nasional, maupun Internasional, yang menjadi prestasi dan prestise bagi penari, kelompok, dan daerah yang mewakili.

\section{KESIMPULAN}

Salah satu hal yang melekat pada Pajoge Angkong adalah, kharisma dan pesona yang dimiliki melebihi kaum perempuan. Hal tersebut tidak lepas dari upaya gigih yang dilakukan Pajoge Angkong dalam merawat diri baik dari dalam maupun dari luar. Baik menggunakan ramu-ramuan maupun kekuatan magis yang membuat kecantikan mereka memancar di atas panggung. Tidak tanggung-tanggung seorang Pajoge akan mencari ilmu kebatinan sampai dipelosok-pelosok kampung, terutama ilmu tentang bagaimana cara memikat mata-hati dari pada kaum laki-laki dan pappasompe yang datang menonton. Salah satu ilmu pemikat yang digunakan adalah cenningrara.

Perjalanan Pajoge Angkong dalam berbagai setting masa, yakni masa orde lama, orde baru, orde reformasi, dan orde kini membawa stigma yang positif dan negative di kalangan masyarakat. Akan tetapi Stigma Pajoge lambat laun menghilang seperti dugaan pemaknaan konotatif dalam masyarakat Bugis Bone. Hal tersebut disebabkan karena dalam sekelompok Pajoge Angkong maupun Pajoge Makkunrai khusunya, boleh jadi terdapat fakta demikian seperti dalam bayangan masyarakat Bugis Bone masa lampau. Akan tetapi ketika menelusuri secara mendalam terkhusus 
kepada Pajoge Makkunrai, bahwa keterlibatan mereka dalam sebuah kelompok Pajoge adalah salah satu bentuk aktualisasi diri, mengisi waktu lowong selain menenun sarung sutera, sembari menunggu jodoh yang tepat menghampiri.

\section{DAFTAR PUSTAKA}

Ahimsa-Putra, H. S. (2000). Wacana Seni dalam Antropologi Budaya: Tekstual, Kontekstual, dan Post-Modernistis. HS Ahimsa-Putra, Ketika Orang Jawa Nyeni, $399-427$.

De Marinis, M. (1993). The semiotics of performance. Indiana University Press.

Hadi, Y. S. (2007). Kajian Tari: Teks dan Konteks. Pustaka Book Publisher.

Hadi, Y. S. (2018). Revitalisasi Tari Tradisional. Dwi-Quantum.

Holt, C. (1939). Dance quest in Celebes. Libr. GP Maisonneuve.

Johariana, J. (2018). Keberadaan Tari Pajoge Angkong di Kabupaten Bone Johariana. Universitas Negeri Makassar.

Nadjamuddin, M. (1982). Tari Tradisional Sulawesi Selatan. Bhakti Baru.

Naziah, S. F. (2019). Pembelajaran Tari Jumpritan untuk Meningkatkan Kemampuan Motorik Kasar Anak Kelompok A di Taman Kanak-kanak Hasyim Asy'ari Surabaya. UIN Sunan Ampel Surabaya.

Pramutomo, R. M. (2007). Etnokoreologi Nusantara Batasan Kajian Sistematika dan Aplikasi Keilmuannya. Surakarta: ISI Press.

Royce Peterson, A. (1980). The anthropology of dance,[1977]. Bloomington/London: Indiana University Press.

Sachs, C. (1933). trans. B. Schönberg (1937). World History of the Dance. 